American University Washington College of Law

Digital Commons @ American University Washington College of

Law

Contributions to Books

Scholarship \& Research

2012

\title{
Efficiency in Bello and Ad Bellum: Making the Use of Force Too Easy?
}

Kenneth Anderson

American University, Washington College of Law, kanders@wcl.american.edu

Follow this and additional works at: https://digitalcommons.wcl.american.edu/facsch_bk_contributions

Part of the International Law Commons, Military, War, and Peace Commons, and the National Security Law Commons

\section{Recommended Citation}

Anderson, Kenneth, "Efficiency in Bello and Ad Bellum: Making the Use of Force Too Easy?" (2012).

Contributions to Books. 122.

https://digitalcommons.wcl.american.edu/facsch_bk_contributions/122

This Book Chapter is brought to you for free and open access by the Scholarship \& Research at Digital Commons @ American University Washington College of Law. It has been accepted for inclusion in Contributions to Books by an authorized administrator of Digital Commons @ American University Washington College of Law. For more information, please contact kclay@wcl.american.edu. 


\title{
14
}

\section{EFFICIENCY IN BELLO AND AD BELLUM: MAKING THE USE OF FORCE TOO EASY?}

\author{
Kenneth Anderson
}

\section{Introduction}

Targeted killing by means of drone warfare has been the subject of much criticism over the past decade, particularly as the United States has increased its pace, intensity, and geographic range since the Obama Administration took office in 2009. The criticisms range widely in their complaints. They include claims that civilian deaths are excessive and disproportionate; "blowback" and resentment in Pakistan and other places produces more terrorists and fighters in the future; drone warfare "de-humanizes" warfare and creates a "Playstation" mentality toward killing; targeting decisions lack transparency and legal standards, particularly with regard to strikes undertaken by the CIA; secret strikes in Pakistan, Yemen, and beyond violate international law; targeted killing outside of a conventional battlefield constitutes extrajudicial execution and violates international human rights law; and many more.

Some of these criticisms are essentially factual in nature, while others are normative claims from law or morality. The claim of excessive civilian deaths-a claim that figures centrally in many of the normative arguments-depends upon facts that are highly contested. Some observers, especially European activists, say that the civilian deaths run in the hundreds or even thousands. The CIA and the U.S. government, by contrast, insist that the civilian death toll amounts to scores over all the years of targeted killing using drones in Afghanistan and Pakistan, and that the rate of civilian deaths continues to decline, year by year, even as the number of strikes increases, due to improved technology and intelligence. The activists and campaigners look for their numbers in local reports from the remote and inaccessible (to Western outsiders) places in Pakistan's border regions. The U.S. government responds that those reports are uncorroborated by Western journalists, typically 
exaggerated or wrong, and sometimes manipulated by Taliban or Pakistani military intelligence.

Beyond that factual argument, a general criticism can be leveled against the U.S. government for refusing to be more forthcoming about its targeted killing and drone warfare programs. The U.S. government says (frequently in leaks to the press that preclude effective public discussion) that its claims of extraordinary precision and low collateral damage levels should be believed, but then offers no independent proof on which to do so. The U.S. government (were it not in the position of offering no official comment) could reply that even apparently innocuous revelations on collateral damage amounts to handing the Taliban, Al Qaeda, and other hostile groups provide invaluable intelligence on how the United States conducts these operations. Broadly speaking, even the arguments over transparency and accountability, however, come down mostly to factual questions. If the United States is right regarding collateral damage, that says one thing. If the activist critics are right, it says another. But these are largely arguments about facts on the ground.

In this chapter, I propose to set aside these factual arguments and instead take certain factual premises by assumption. My purpose is to focus instead upon an argument over targeted killing using drones in which, importantly, the form of argument itself is at issue. The bare-bones argument is the following. Targeted killing using drone warfareis immoral because, by removing the personal risk to those carrying out these operations, the drone-wielding actor has no, or much reduced, disincentives against using force. Using force when your own people are not at risk in the operation makes using force "too easy" an option.

The argument comes in several different forms, with levels of detail, sophistication, and formality. Perhaps the simplest version is that offered by a campaigning lawyer, who said, "The problem with drones is that they remove the burden of having to fight one's way on the ground to the target, and so remove the constraints of geography and personal risk in warfare, so increasing the temptation to make war." Another version says that, since such attacks cause civilian casualties, reducing the personal risk to the drone-using forces increases civilian casualties that would not otherwise occur-even if they are still relatively small-and this is unjust. Still another version goes so far as to accept that drones might reduce, rather than increase civilian casualties-but the very fact of decreasing civilian casualties increases the propensity to use force in the first place, and this is a bad idea.

Versions of this general argument about drones are widely circulated in the press and literature about U.S. counterterrorism; those of us who participate in academic and policy conferences about drones and targeted killing find them to be an oft-repeated trope. Many of the references appear to trace back to comments in Brookings scholar Peter Singer's path-breaking book, Wired for War, and later 


\section{Targeted Killings}

a widely noticed 2009 article by New Yorker writer Jane Mayer. The prominent British computer scientist Noel Sharkey also brought these arguments to public awareness in articles in The Guardian. Versions of them were repeated in a recent U.K. Ministry of Defence report on robotics and drone warfare. Whatever precisely the version of the argument, however, or by whomever offered, the final conclusion is typically that drones make war "too easy."

The factual and normative claims are often closely associated with criticisms of drones based on affective claims, claims about the emotions of drone operators and targeters, on the one hand, or those in the targeting zone, whether targets or civilians, on the other. The affective criticisms include the supposed de-personalization of war by drones and a supposed de-sensitization toward violence on the part of drone operators. This is a claim about the affective consequences of the remoteness of the weapon platform and its operators from the place of killing, and not only solely the lack of personal risk for the operators. This was vividly spelled out in a Newsweek Article in which a CIA officer describes how he would watch these killings live on a monitor while sitting comfortably in his office. ${ }^{1}$ Sometimes these criticisms lead to a different kind of criticism. Virtuous warfighters are somehow obligated to view each death, including those of acknowledged enemies, who threaten American soldiers or as terrorists, Americans generally, as "regrettable." So, in that case, it would be unseemly for U.S. personnel to cheer a drone attack upon a fleeing terrorist, because that would show callous indifference to human life; the proper attitude is regret even in killing an enemy who might, if not killed, be engaged in killing Americans.

The attitude of "remoteness" that is called for in the name of virtue seems to me quite morally unjustified. Indeed, it is that form of remoteness, the idea that one refuses to address the question of "sides" in war in the name of pure abstraction, which seems to me a much more problematic form of "remoteness," not remoteness in launching the missile from a physically remote place. But the proper balance of attitude and affect in the honorable and just warrior, as between the emotions of partiality and impartiality, carry us far afield into questions of virtue ethics that I will not address here.

Affective arguments often hint, nonetheless - even if inchoately - that war without personal risk is unchivalrous and dishonorable. It is a point that has featured in "blowback" criticisms — critiques of targeted killing using drones that argue it is counterproductive because of the resentment it produces among populations in Pakistan and elsewhere. As a psychological proposition, it is perhaps unsurprisingly featured in fictional literature about the war on terror-perhaps most

1 Tara McKelvey, "Inside the Killing Machine," Newsweek, February 13, 2011 <http://www. thedailybeast.com/newsweek/2011/02/13/inside-the-killing-machine.html> accessed November 4, 2011 


\section{Making the Use of Force Too Easy?}

prominently in Blood Money, the recent thriller written by Washington Post columnist David Ignatius. ${ }^{2}$ It has been raised by many pundits - LA Times columnist Doyle McManus, for example ${ }^{3}$ — and is a core critique for counterinsurgency experts such as Andrew Exum or David Kilcullen, who believe that targeted killing using drones is an affectively wrong strategy because anonymous, invisible, and impersonal "death from above," as it were, works against winning hearts and minds of local populations on the ground. ${ }^{4}$

The surface framing of these many and jumbled versions of the "too easy" argument against drones hints at buried premises. This chapter proposes to examine some of these buried premises. At bottom, however, I want to urge that there is something wrong with the conceptual form of this argument, in which a successful strategy in war turns out to be immoral, not because of the damage it causes achieving its success, but because success itself increases the propensity to do it too much. The problem is not with the argument that even a successful strategy can lead to unintended consequences of its own success-including the tendency to overuse it. True, one ought to view such criticisms of success with considerable skepticism-does one really want to proceed from a heuristic of "whatever you do, avoid success because you might overdo it?" It seems better to acknowledge that, at most, such criticism is a "second-order" problem, if a problem at all. The fundamental problem with this argument does not lie there.

It lies instead with the fundamental idea that drones make the resort to force and violence-war- "too easy." Attractive on the surface, it is not a coherent notion as applied in war. The most interesting and important version of the argument goes so far as to frame this as a matter of creating an "inefficient" level of disincentive to use of force on account of insufficient risks to one's own forces in so doing-appealing deliberately to the apparatus of welfare-maximization and cost-benefit analysis. That there is an "inefficient" level of incentive to use violence presumes, however, that there is in principle an "efficient" one. I will argue that this is conceptually faulty.

I believe this to be a bad argument, not so much on account of faulty factual premises about drones and targeted killing, but primarily on account of faulty reasoning about the place and role of "efficiency" in thinking about the resort to force. But whether I am right or wrong on this point, the argument is nonetheless of intrinsic interest because it involves an important and overlooked intertwining

2 David Ignatius, Blood Money (W.W. Norton Publishing, 2011).

3 Doyle McManus, "U.S. drone attacks in Pakistan 'backfiring,' Congress told," LA Times, May 03, 2009, <http://articles.latimes.com/2009/may/03/opinion/oe-mcmanus3> accessed November 3, 2011.

4 David Kilcullen and Andrew McDonald, "Death From Above, Outrage Down Below," NY Times, May 16, 2009 <http://www.nytimes.com/2009/05/17/opinion/17exum.html> accessed November 3, 2011. 


\section{Targeted Killings}

of two strands of the ethics of war, the rules governing the conduct of war (jus in bello) and the rules governing the resort to force (jus ad bellum). There is intrinsic interest to the argument that the "efficiency" of jus in bello might create "inefficiency" of jus ad bellum.

To be clear at the outset, the argument criticized here is the universal argument that makes claims about either morality or efficiency for all parties taken together-the two acknowledged sides as well as the civilians on both sides. It needs to be distinguished from a distinct debate over targeted killing using drones that is essentially strategic and runs to one side's interests only. David Ignatius, for example, has been arguing in a series of influential columns in the Washington Post that the United States is "addicted" to drones because they make it "too easy" to decide to attack in many places. ${ }^{5}$

This sounds very much like the argument that this chapter critiques, but Ignatius and others making this assertion are not making a claim about the morality or efficiency of drones on a universal ground. The claim, rather, is that considered only with respect to its own strategic interests, the United States overuses drones. Ignatius' claim is roughly that, as a matter of U.S. counterterrorism strategy (morality or universal welfare efficiency aside, just as a matter of U.S. strategy), the problem with drones is that they are tactically precise, but strategically incontinent. I believe that claim is incorrect, but it is essentially a factual question, and not the argument under consideration here.

The order of discussion is as follows. First, I set out several key factual assumptions about drone warfare, precision targeting, and civilian collateral damage. These assumptions are set against a background discussion of the nature of the drone campaign and targeted killing as currently conducted by the United States. The key descriptive point is to disentangle the technology of drone warfare from the practice of targeted killing; the two are not always linked, and are not the same thing or always aimed at the same strategic goal. Second, I set out the form of the argument that I propose to critique in what-given the factual assumptions-I take to be its most plausible, but also most sophisticated and interesting conceptual form. The essential task here is to unpack the intuition lying behind the oft-heard phrase in this context, drones make war "too easy." Third, I critique the web of conceptual assumptions that underlie the very idea that there is a coherent way to talk about drones making war "too easy" - which is to say, some notion of an "efficient" level of war that could make sense of saying that it is either "too easy" or "too hard." Fourth, assuming that the critique offered of the notion of an "efficient" level of the resort to force-war-is good, I finally turn to offer a speculative and incomplete

\footnotetext{
5 David Ignatius, “The Price of Becoming Addicted to Drones," Washington Post, September 22, $2011<$ http://www.washingtonpost.com/opinions/the-price-of-becoming-addicted-todrones/2011/09/21/gIQAovp41K_story.html> accessed November 3, 2011.
} 


\section{Making the Use of Force Too Easy?}

account of why that would be so. Here, I will argue that war turns on the nature of "sides" that do not share commensurable grounds that would allow the commonality required to find an "efficient" point in a universal welfare sense.

\section{Disentangling targeted killing and drone warfare}

Although targeted killing and drone warfare are often closely connected, they are not the same and are not always associated with each other. We need to disaggregate the practices of targeted killing from the technologies of drone warfare.

Targeted killing consists of using deadly force, characterized by the identification of and then strike against an individual marked to be killed. It is distinguished, among other things, by making an individualized determination of a person to be killed, rather than simply identifying, for example, a mass of enemy combatants to attack as a whole. Since it is a practice that involves the determination of an identified person, rather than a mass of armed and obvious combatants, it is a use of force that is by its function integrated with intelligence work, whether the intelligence actors involved are uniformed military or a civilian agency such as the CIA.

Targeted killing might (and does) take place in the course of conventional warfare, through special operations or other mechanisms that narrowly focus operations through intelligence. But it might also take place outside of a conventional conflict, or perhaps far from the conventional battlefields of that conflict, sufficiently so operationally, to best be understood as its own operational category of the use of force- "intelligence-driven," often covert, and sometimes non-military intelligence agency use of force, typically aimed at "high value" targets in global counterterrorism operations. It might be covert or it might not-but it will be driven by intelligence, because of necessity it must identify and justify the choice of target (on operational grounds, because resources are limited; or legal grounds; or, in practice, both).

Targeted killing might use a variety of tactical methods by which to carry out the attack. The method might be by drones firing missiles- the focus of discussion here. But targeted killing — assassination, generically — is a very old method for using force and drones are new. Targeted killing in current military and CIA doctrine might, and often does, take place with covert civilian intelligence agents or military special operations forces-a human team carrying out the attack, rather than a drone aircraft operated from a distance. The bin Laden raid exemplifies the human team-conducted targeted killing, of course, and in today's tactical environment, the United States often uses combined operations that have available both human teams and drones, to be deployed according to circumstances. 


\section{Targeted Killings}

Targeted killing is thus a tactic that might be carried out either by drones or human teams. If there are two ways to do targeted killing, there are also two functions for the use of drones - targeted killing as part of an "intelligence-driven" discrete use of force, on the one hand, and a role (really, roles) in conventional warfare. Drones have a role in an ever-increasing range of military operations that have no connection to "targeted killing." For many reasons ranging from cost-effectiveness to mission-effectiveness, drones are becoming more ramified in their uses in military operations, and will certainly become more so. This is true starting with their fundamental use in surveillance, but it is also true when they are used as weapons platforms.

From the standpoint of conventional military operations and ordinary battlefields, drones are seen by the military as simply an alternative air weapons platform. One might use an over-the-horizon manned aircraft_or, depending on circumstances, one might instead use a drone as the weapons platform. It might be a missile launched from a drone by an operator, whether sitting in a vehicle near the fighting or farther away; it might be a weapon fired from a helicopter 20 miles away, but invisible to the fighters; it might be a missile fired from a U.S. Navy vessel hundreds of miles away by personnel sitting at a console deep inside the ship. Future air-to-air fighter aircraft systems are very likely to be remotely piloted, in order to take advantage of superior maneuverability and greater stresses endurable without a human pilot. Remotely-piloted aircraft are the future of much military and, for that matter, civil aviation; this is a technological revolution that is taking place for reasons having less to do with military aviation than general changes in aviation technology.

Missiles fired from a remotely-piloted standoff platform present the same legal issues as any other weapons system-the law of war categories of necessity, distinction and proportionality in targeting. To military professionals, therefore, the emphasis placed on "remoteness" from violence of drone weapons operators, and presumed psychological differences in operators versus pilots, is misplaced and indeed mystifying. Navy personnel firing missiles from ships are typically just as remote from the fighting, and yet one does not hear complaints about their indifference to violence and their "Playstation," push-button approach to war. Air Force pilots more often than not fire from remote aircraft; pilots involved in the bombing campaign over Serbia in the Kosovo war sometimes flew in bombers taking off from the United States; bomber crews dropped their loads from high altitudes, guided by computer, with little connection to the "battlefield" and little conception at what they — or their targeting computers — were aiming. Some of the crews in interviews described spending the flights of many hours at a time, flying from the Midwest and back, as a good chance to study for classes they were takingnot Playstation, but study hall. In many respects, the development of new sensor technologies make the pilots, targeters, and the now-extensive staff involved in a 


\section{Making the Use of Force Too Easy?}

decision to fire a weapon from a drone far more aware of what is taking place at the target than other forms of remote targeting, from Navy ships or high altitude bombing (but presumably the bombers did not drop their loads until they were over the battlefield, although they were very high over it).

Very few of the actors on a technologically advanced battlefield are personally present in a way that makes the destruction and killing truly personal-and that is part of the point. Fighting up close and personal, according to the critics' psychological theories, seems to mean that it has greater significance to the actors and therefore leads to greater restraint. That is extremely unlikely and contrary to the experience of U.S. warfighters; lawful kinetic violence is more likely to increase when force protection is an issue and overuse of force is more likely to increase when forces are under personal pressure and risk. The U.S. military has known since Vietnam at least that increased safety for fighting personnel allows them greater latitude in using force, encourages and permits greater willingness to consider the least damaging alternatives, and that putting violence at a remove reduces the passions and fears of war and allows a coolly professional consideration of what kinds, and how much, violence is required to accomplish a lawful military mission. Remote weapon systems, whether robotic or simply missiles launched from a safe distance, in U.S. doctrine are more than just a means for reducing risk to forces - they are an integral part of the means of allowing more time to consider less harmful alternatives.

This is an important point, given that drones today are being used for tasks that involve much greater uses of force than individualized targeted killing. Drones are used today, and with increasing frequency, to kill whole masses of enemy columns of Taliban fighters on the Pakistan border - in a way that would otherwise be carried out by manned attack aircraft. This is not targeted killing; this is conventional war operation. It is most easily framed in terms of the abstract strategic division of counterinsurgency from counterterrorism (though in practice the two are not so distinct). In particular, drones are being deployed in the AfPak conflict as a counterinsurgency means of going after Taliban in their safe haven camps on the Pakistan side of the border. A fundamental tenet of counterinsurgency is that the safe havens have to be ended, and this has meant targeting much larger contingents of Taliban fighters than previously understood in the "targeted killing" deployment. This could be- and in some circumstances today is-being done by the military; it is also done by the CIA under orders of the President partly because of purely political concerns; much of it today seems to be a combined operation of military and CIA.

Whoever conducts it and whatever legal issues it might raise, the point is that this activity is fundamentally counterinsurgency. The fighters are targeted in much larger numbers in the camps than would be the case in "targeted killing," and 


\section{Targeted Killings}

this is a good instance of how targeted killing and drone warfare need to be differentiated. The targets are not individuated, either in the act of targeting or in the decision of who and where to target: This is simply an alternative air platform for doing what might otherwise be done with helicopters, fixed wing aircraft, or ground attack, in the course of conventional counterinsurgency operations. But it also means that the numbers killed in such operations are much larger, and consist often of ordinary fighters who would otherwise pile into trucks and cross back into Afghanistan, rather than individualized "high value" targets, whether Taliban or Al Qaeda.

Disentangling targeted killing (whether by drones or human teams) from drone warfare (whether for targeted killing or conventional warfare) is important because the argument upon which this chapter focuses goes to the category of targeted killing by means of drones. It depends upon a factual assumption about the civilian consequences of targeted killing using drones; upon a further fact about the reduced risk to U.S. personnel in such operations; and about a supposed implication for the incentives or, more precisely, supposedly reduced disincentives to resort to violence under those two conditions. But it is therefore not about targeted killing using human teams; and it is likewise not about drones used for conventional warfare.

\section{An assumption about civilian casualties and collateral damage}

The undefended factual assumption of this argument is that targeted killing using drones results in significantly_vastly_less collateral damage and civilian deaths than other forms of attack. The alternatives include other forms of attack from manned attack aircraft, or attack by human special operations teams on the ground. It is true that there would presumably be no collateral damage if no attack were carried out at all, but that alters the fundamental question beyond recognition. This chapter takes that assumption as given and does not defend it, but it is worth saying something as to why this is a plausible and, at this date, the best assumption regarding civilian harm from targeted killing using drones.

The main approaches to collateral damage from targeted killing using drones in Afghanistan and Pakistan are three: first, various European campaigning groups purport to report using local sources, such as Pakistani newspapers and local media or governmental statements. Second, two American groups-with notably distinct political tendencies, the generally liberal New America Foundation and the generally conservative Long War Journal ${ }^{6}$ (Bill Roggio of the Foundation for the Defense of Democracies)— have each been estimating strikes and apparent

\footnotetext{
${ }^{6}<$ http://www.longwarjournal.org/pakistan-strikes.php> accessed November 3, 2011.
} 


\section{Making the Use of Force Too Easy?}

civilian casualties since the mid-2000s. Third, although the U.S. government does not comment openly on CIA operations or other secret strikes, senior officials have made anonymous comments to reporters, but more recently directly on the record, on what the U.S. claims are the levels of civilian casualties.

The general lines of those three, at this writing, can be summarized thus. The European campaigning groups suggest hundreds to thousands of civilian casualties over the decade that the United States has been engaged in such strikes. The New America Foundation ${ }^{7}$ and the Long War Journal have separately estimated civilian casualties in the various hundreds; their evaluations today suggest that despite sharply escalating levels of strikes, the rate of civilian casualties has been declining in the last two years. The U.S. government has offered estimates, nearly all off the record, of a hyperbolic "zero" to civilian casualties in the two (sometimes said to be low two) digits. ${ }^{8}$ Some important notes on what counts in these attempts at tabulation are required. First, outsiders do not have direct, ground level access to strike locales, and so casualty counts are very much a function of local reports, which everyone grants carry much possibility of exaggeration or propaganda manipulation. It is not even clear the extent to which U.S. intelligence has access to on the ground reports; it seems to rely heavily on continued Predator drone air surveillance to see what happens on the ground following a strike to determine who was killed, though it might well have intelligence assets on the ground as well. ${ }^{9}$

In my opinion as an informed (though entirely outside the government) observer, the truth of the matter is likely higher than the U.S. government says, and unquestionably higher than its lowest (zero) estimate-but at most in the low hundreds, if not high two digits. If that is so, certainly I would endorse what former CIA director Leon Panetta has said about this technology_ "It is the most accurate weapon system in the history of warfare." That is so, frankly, even if the numbers are the higher, earlier estimates given by the American monitors. (For what it is worth, I do not give much credence to the European campaigners' estimates, though they are politically influential in various quarters, but even those estimates, compared to the history of civilian deaths in war, represent a very considerable improvement. This is not intended as a legal judgment as to proportionality, which would require many separate considerations. The point, rather, is that these technologies are making targeting in war more precise on any historical measure, and criticizing them on a snapshot basis_-your technology killed civilians, it's another war crime-rather than on their historical trend line, the horrors of urban battles in the Second World

\footnotetext{
7 <http://counterterrorism.newamerica.net/drones> accessed November 3, 2011.

8 <http://www.guardian.co.uk/commentisfree/cifamerica/2011/aug/11/civilian-victims-ciadrones $>$ accessed November 3, 2011.

9 For more on the trustworthiness of these numbers, see Gregory McNeal, "Are Targeted Killings Unlawful? A Case Study in Empirical Claims without Empirical Evidence" in this Volume, ch. 12.
} 


\section{Targeted Killings}

War as a baseline, seems to me morally indefensible. One should be encouraging improvements that will necessarily be incremental and over a long time.)

Second, understanding the separate roles of drones in targeted killing of individually identified terrorist targets as part of counterterrorism, on the one hand, and conventional counterinsurgency warfare targeting cross-border safe havens, camps, and columns of mass groups of Taliban fighters, on the other, is important in interpreting any of these estimates. The groups attempting to estimate numbers do not seek to disaggregate these roles, and thus total numbers killed might well go up or down significantly as a function of conventional combat in Afghanistan, not as a result of counterterrorism operations. Targeted killing using drones in the sense meant in this discussion is illustrated by an attack upon an Al Qaeda commander in the Pakistan border areas, not necessarily connected to Afghanistan Taliban operations or the safe haven camps for fighters but instead, for example, a person with a planning role for operations to be carried out abroad. But with respect to counting casualties, that $\mathrm{Al}$ Qaeda counterterrorism target is more likely to be surrounded with civilians, whether explicitly as human shields or not, than fighters in the camps or in transit across the Afghan border. The ratio of civilians to Al Qaeda target killed might be high, even though the total number of people is small in absolute terms; by contrast, an attack upon a camp might easily have no genuine civilian killed, but may kill large numbers of fighters in absolute terms. Add to that a third dimension of the value of the target - high value taken as an individual in the targeted killing of the Al Qaeda commander in counterterrorism; low value taken individually in the case of any individual Taliban fighter, but high value taken altogether as a fighting force in counterinsurgency.

These considerations indicate that the aggregate numbers of killed, civilians or targeted persons, for drone operations sometimes reported in the press and by monitors such as Long War Journal or the New America Foundation, do not tell us everything about casualty numbers that we need to know, particularly as the uses of drones ramify - as these monitors would be the first to agree (they have been admirably transparent as to the limitations of the methodology). Reporting on casualties from drone warfare is not the same as reporting on casualties from targeted killing as such. It is unclear whether the leaked statements about casualties from the CIA refer only to CIA strikes, and only to strikes carried out as genuine targeted killing. This is a very significant ambiguity in the statements, of course. Hence the granular differences matter.

The assumption of this chapter, therefore, is that targeted killing using drone technologies is significantly more discriminating and sparing of collateral damage to civilians and their property than alternative uses of force to the same end would be. That is so whether the actor is the military in conventional operations, military special forces, the CIA, or combined special operations. I happen to think that 


\section{Making the Use of Force Too Easy?}

proposition is true and that it is becoming more so over time-an indication of the importance of allowing incremental improvements in weapons systems, rather than smothering the technological baby at birth. I also think the perception of greater precision leading to fewer civilian casualties is increasing even among skeptics of targeted killing using drones, including some of the human rights monitors, who today appear to be hanging back from full-on criticism of the technology and its possibilities. The fact of NATO having urgently requested, and received, Predator drones as attack platforms in the Libya conflict has also apparently had an effect. After the outbreak of the NATO air war, Qaddafi's forces quickly abandoned their tanks and heavy equipment, as NATO promptly targeted them with conventional aircraft, to mingle with civilians in ways that made locating them much more difficult.

Drones were first used to help identify targets in Libya — the surveillance role for which Predators were originally designed, with long loiter times over the battlefield (hours compared to precious minutes). But NATO quickly determined that it was both more effective and safer for civilians if the drones undertook the strike as quickly as possible, rather than waiting for manned aircraft to arrive. This role of drone aircraft in a "humanitarian" war seems to have put drones in a somewhat different light from how they appear- "anonymous death from the skies"- to their critics in Afghanistan and Pakistan, though without any particularly logical reason why it should be so, and appear to have done something to "bless" drones as more acceptable than they were. It has not escaped attention that drones are a near perfect weapon of humanitarian intervention if there is an associated force on the ground-one's own troops are not at risk, and yet, at least in Libya, the war is not entirely an (oft-indecisive) air war, either. Of course, consonant with the burden of this chapter, what might be seen as a "feature" of drones - they do not put riskaverse humanitarian interveners at risk-might just as easily be seen as the "bug" of this chapter - they make armed humanitarian intervention "too easy."

Speaking to the broad future of the technology, however, and given the direction of technology and cost, it appears inevitable that drones will take on many more operational roles over time, whether in conventional war, special operations, and what has here been called generically "intelligence-driven uses of force." Drones will likely evolve-as aircraft, as well as in the weapons and sensor systems they bear-into many specialized types. They will get both bigger and smaller than they are now, for example, and they will surely evolve into those specialized for surveillance and those specialized to fire weapons. And they will also surely evolve into those specialized in high-value, "intelligence-driven" targeted killing of individuals and those that are suited to conventional operations. Bearing in mind these increasingly varied uses is essential to understanding, when it comes to targeted killing and/or drone warfare, that one-size-fits-all legal analysis is not sufficient. 


\section{Targeted Killings}

One last background observation on the nature of targeted killing through drone warfare. Beyond technology, success in Afghanistan and Pakistan, and anywhere beyond, depends crucially upon on-the-ground intelligence long before any Predator is launched. It is an underappreciated point—very underappreciated. The United States has invested many years in the past decade of war in Afghanistan in establishing its own intelligence network on the ground that is able to supply information with respect to both counterinsurgency operations on both sides of the border, as well as with counterterrorism activities and targeting inside Pakistan. This has taken years, and, particularly during the last five years, the CIA has been the lead agency. This is a reason why the CIA, rather than the military, is tasked with much of the drone use in the border areas of Pakistan; it has the intelligence networks. This is also a source of irritation to the Pakistani government, which is no longer able to steer US targeting and intelligence activities.

But the precision of strikes with respect to civilian casualties, and also the ability to determine who the United States should target and ensure that this is the person actually being targeted by a drone, is a function of the CIA's intelligence capabilities on the ground, integrating a human network together with signals intelligence. This was the background that led to the successful bin Laden raid in 2011 — and a key source of the Pakistani government's chagrin, that the United States did not need it and would possibly have been compromised in the operation. It is also instructive to compare the difficulties of the Libya air campaign, even with weaponized drone aircraft, with the U.S. capabilities in Afghanistan and Pakistan. The mere fact of drone technology in Libya helped targeting considerably, in the actual moment of fighting, but simply having drone capability could not make up for a lack of ground level intelligence networks. Afghanistan, by contrast, after 10 years of high technology war, is one of the most thoroughly mapped spaces in the world, ironically, even as it remains one of the least governable-mapped in natural, built, and social terms with respect to targeting and selection of least harmful weapons systems, as Gregory McNeal has observed ${ }^{10}$.

Ground level intelligence operations are a vital part of making precision weapons precise; drone technology cannot make up for that capability, just as reliance upon pure signals intelligence is insufficient to direct targeting. All must be integrated. The drone is the sharp tip of a spear. But behind the sharp tip is the thin tail (to employ mixed metaphors) of intelligence operations that constitute the bulk of activities. Drones are only as useful as their supporting intelligence, and the only kind that works over the long run, as Libya teaches in one direction and Afghanstan in the other, are dense ground-level networks of human intelligence integrated with signals intelligence and long-running drone surveillance.

10 Ibid. 


\section{Making the Use of Force Too Easy?}

What this points to, however, is that a view of drone warfare sometimes offered, of roving drones that observe from the sky, gather information, and then attackglobally roving birds of prey, so to speak-is simply wrong. A large part of this is intelligence required for useful and accurate targeting. But drones also require infrastructure-runways, bases, repair and maintenance, refueling, and the personnel to support all of that. The fact that they might be piloted from the United States does not change the very considerable physical infrastructure required to support them, relatively close to actual operations and of course not in Nevada or Langley. Drones are better understood, though not as "global," but instead as aircraft flown from, but finally tethered to, a (metaphorical) aircraft carrier-roving with a certain range, but always strictly tethered and entirely dependent upon a base. Far from being free-roving global birds of prey, they are instead the last kinetic step in a long, dense, and intensely local intelligence and infrastructure operation.

\section{The argument that drones make resort to war "too easy"}

The preceding two sections aim at giving some practical background of targeted killing and drone warfare, and particularly in disentangling the two. They also aim to provide at least some background for why I regard the fundamental, but undefended, factual assumption of this chapter to be not just plausible, but likely correct and likely to be more correct over time. That assumption is that, in fact, targeted killing using drone technologies significantly reduces civilian casualties and civilian harms in comparison to alternative means of using force. This assumption assumes certain other background assumptions, raised in the earlier discussion, that intelligence resources are available to direct the targeting toward intended targets; the precision in the weapon as a whole system is more than simply technological precision, it is an integrated process of "intelligence-driven" uses of force.

In addition, the argument assumes something that is not disputed-the use of remotely-piloted drones removes the personal risk to one's own forces. For these purposes, we will ignore reports that those who fire weapons from drones, even when located safely in the United States and as far from the kinetic battlefield as can be, suffer from psychological stress similar to that of pilots and others much closer to the battlefield. Those reports raise important issues, and would appear to run contrary to suggestions of a "Playstation" mentality toward killing using drone technologies, but for our purposes, harm to civilians and risk to own-forces will be taken as purely physical.

The most interesting version of the argument runs thus (I will refer to the argument that links a jus in bello consideration to a jus ad bellum one as the "overall" or "general" argument): 
- Given that targeted killing removes personal risk to the attacker's forces; and

- even if targeted killing using drones reduces civilian harms and collateral damage;

- the use drones in targeting killings is nonetheless (at least possibly) undesirable because those very factors (might possibly) lower the disincentives to the attacker resorting to force, (possibly) to an inefficient equilibrium with respect to the propensity of a attacker to resort to force.

Let us break this down piece by piece. The argument has two opening conditionals, the first undisputed and the second taken by assumption-removing personal risk to attackers and reducing civilian harm. These two each fall under the general heading in the law and ethics of war of " jus in bello"-the rules governing the conduct of hostilities. The jus in bello assumptions are striking, on their own, because they essentially say that military technology has lowered both the risk to one side's military combatants and to noncombatants. From the standpoint of the conduct of hostilities, jus in bello, this is a good thing.

It is, however, more than just a good thing-it is a double-plus good thing, so to speak. After all, ordinarily the problem in the conduct of hostilities is that what is good for one side's military operations is bad not just for the other side but for civilians as well. This leads to the famous "proportionality" calculus for military operations and collateral damage: "The benefits of a military operation must be weighed against the civilian harms, and the civilian harms cannot be "excessive" in relation to the military benefits." The trouble with the proportionality calculus in jus in bello, however, is that it notoriously seems to pit apples against oranges, incomparable values of one side winning versus civilian harm. Everyone agrees that in some gross manner, judgments must be made, but the judgment not only lacks clear criteria in the law, it is far from evident that conceptually it can be done save by purely casuistical means-we did this in that case and believed it acceptable, and this case is more or less like that case, and so on.

The conceptual problem that I find in the overall argument about targeted killing using drone technology is not based upon the famously difficult problem of a calculus of proportionality necessarily involving incommensurables. On the contrary, one intriguing element of this version of the argument is that it sidesteps that proportionality issue altogether. Or, rather, if the facts ascribed to the technology are correct, technology provides a deus ex machina and an escape from the jus in bello proportionality trap. After all, everything in the jus in bello category here works together, not against each other. The technology provides force protection to (one side's) combatants; it provides greater protection to civilians through precision targeting. What's not to like? No weighing up of perplexing values need to take place, because everything is on the plus side, win-win. 


\section{Making the Use of Force Too Easy?}

The bite of the overall argument, however, assuming it is correct, is that precisely these virtues on the jus in bello side make the technology a vice on the side of the resort to force, jus ad bellum. Or, more exactly, a vice with regard to the propensity to resort to force, jus ad bellum. The idea that making war itself more humane-including by creating legal codes for the conduct of war-has always given rise to arguments that humanizing war reduces the disincentives to engage in it. Florence Nightingale, for example, put the matter brusquely in a letter to the founder of the International Committee of the Red Cross as an objection (though later she was to become a strong supporter of the Red Cross movement):

because first, such a Society... would relieve (governments) of responsibilities which really belong to them which they only can properly discharge... and being relieved of which would make war more easy. ${ }^{11}$

The greatest moral opprobrium for the use of drones, however, is generally focused, not upon the assumption that they spare civilians, but instead upon the proposition that they spare the attackers from personal risk. Most of those who make this general form of argument against drones- "too easy"-probably do not believe or discount the "greater civilian protection" assumption. That ultimately comes down to facts, but the argument as I have given it above is more illuminating because it holds out the possibility that even if the civilian safety assumption is true, the weapon system is still morally flawed, wrong even, because of the evils of making resort to force "too easy."

That is, the problem with drones is that they pit the benefits of technological advances in jus in bello against the relaxation of disincentives to use force in jus ad bellum. This is quite apart from any special supposed wickedness in a side reducing the personal risks of combat in relation to civilian harm. The special problem with drones that eliminate personal risk to a side's forces is, instead, not only harm in a deontological moral sense, but a special form of anti-social inefficiency. We might call it "wickedness" or "wrongfulness" in an imprecise sense, and we might indulge ourselves in essentially affective objections to unchivalrous ways of waging war. But the objection is to both wickedness and inefficiency. What we mean is not solely injustice-it is also social inefficiency, the special harm in a suboptimal welfare equilibrium sense arising from granting to yourself and your side the privilege of making war without risk to yourself. War becomes, or at least might become, "too easy," in relation to what is otherwise the "efficient" level of the resort to force.

11 See Kenneth Anderson, "First in the Field: The unique mission and legitimacy of the Red Cross in a culture of legality," Times Literary Supplement, July 31, 1998 (reviewing Caroline Moorhead, Dunant's Dream: War, Switzerland and the history of the Red Cross), at <http://papers.ssrn.com/sol3/ papers.cfm?abstract_id=935781 > accessed September 7, 2011 (emphasis added). 


\section{Personal risk}

Surely this is over the top. It seems doubtful that anyone actually talks about the wrongs or harms of war by invoking language, less still arguments, of "suboptimal welfare equilibrium" or "disincentives to the propensity to use force to inefficient levels arising from insufficient personal risk to the attacker's personnel." Or, if this kind of language is used, surely it is merely students sampling the joys of applying an abstract apparatus to the real world; to a student newly-equipped with the Coase Theorem, all situations look like opportunities for Coase bargaining to efficient outcomes. But this argument is one that I have heard offered in various meetings and conferences by professors, students, policy analysts, and journalists, and with admirable seriousness by academics whose intellectual commitments compel them to find welfare-based, apparently rational (in social science terms) ways of expressing a sentiment that might otherwise seem to be about the morality of taking no risks in targeting, or at least the unsportingness of it all, in the only language of value available to them, that of net social welfare and efficiency.

The professors are right to offer a more apparatus-laden way of talking about "too easy," however. "Too easy" captures a loose idea, one that has some intuitive appeal, but making sense of it — or concluding, alternatively, that it does not make sense-requires a more sophisticated statement of it. It merits unpacking. The unpacking can go in the direction of normative moral judgments set within the ethics of war. Or it can go in the direction of seeking to make a neutral judgment that if the criterion for optimal resort to force is $\mathrm{x}$, then changes in the costs and benefits of certain ways of using force can alter the incentives to resort to force, and the resulting equilibrium might be above or below the optimal level, considered on its own. They are right to look to the apparatus of Coasean bargaining to the efficient point, in order to ask what is meant by moving from saying that the existence of these new drone technologies and precision targeting does not simply make the resort to force "easier" but "too easy."

And yet - there is a certain demurral, drawn from (though it will not be pursued here) virtue ethics. The military and those associated with it find this way of expressing the objection to drone warfare particularly objectionable — at least when expressed by itself, in a vacuum, as though this were the only relevant analysis to bring to bear. I both share their sentiment and believe it merits explicit recognition, not because this kind of apparent social-science framing should not be used-but because, when conjoined with an explicit discussion of its affect, it forces to the surface a debate over whether this apparent cool, rational, neutral observation is quite as neutral or rational as it seems. They see through the apparently "neutral" expression of "suboptimal equilibrium for the resort to force" and see instead two casual, contemptuous moral judgments lying just beneath the apparently rational surface: you're trigger-happy and you're cowards. 


\section{Making the Use of Force Too Easy?}

The anodyne expression of a point on a graph of efficiency where jus in bello benefits are outweighed by jus ad bellum costs, and the proposal that the personal risks taken by U.S. warfighters are "insufficient" and "suboptimal" - the apparently bloodless and disengaged analysis conceals, one is tempted to think, a viciousness and a callousness exhibited by those who take the sacrifices of others not gifted with professorships at leading universities a little bit too much for granted. The professional military in the United States are far too careful and, well, professional to say this aloud, even when they appear on exactly the same panels. I have no such qualms. Affect matters because it can help enunciate what we value.

But what lies beneath the anger at these entirely distanced and abstract attitudes toward the risks that are to be imposed on U.S. personnel? Partly, it is because this view of the role of personal risk is simply mistaken, factually wrong. I have already noted that one of the enormously important reasons why drones reduce risk to civilians is precisely that personnel are not at risk. Strikes can be considered with all the coolness possible when one's forces are not at risk-and not under pressure to strike at the moment, to take the shot because the human team cannot linger for hours, days, or weeks to find a better moment. It reveals a profound ignorance of professional military planning - and an arrogant assumption that professors can assume, based on their entirely abstract notions of self-interest, how in fact operational planning takes place. Reducing risk to one's own forces allows greater planning to reduce the harms and effects of military operations.

But it might be said that this misses the point. It might be true, after all, that reducing risk to one's own forces indeed reduces the risk of harm to civilians and reduces overall the damage caused by military operations - this would be an effect of technology, among other things. It would require, too, a military that cared about the harms of military operations. Very well; accepted. But the issue is not that reducing personal risk allows for reductions of risk to civilians; the issue is that reducing personal risk reduces the disincentives to using force at all. Resort to force is the issue here.

Here too, however, the actual experience of U.S. war-planners suggests something quite different. The United States reaches the decision to use force-military levels of force-on a basis that takes risks to troops seriously, but always starts from and is guided by imperatives of national security. Sometimes they will argue in favor of using force; other times they will counsel against. The responsibility for risks to U.S. personnel is always a grave consideration for military and political leadership; it does not follow, however, that this constraint acts as a veto on military actions that otherwise would be taken. The political, strategic, legal, and other disincentives to the use of force in the world are far greater than this argument would credit.

Indeed, there is only one circumstance where, realistically, the ability to avoid casualties altogether by the use of drones would make a serious difference in the 


\section{Targeted Killings}

calculation of whether to go to war. Ironically, that is the matter most desired by some of those who would otherwise argue in favor of increasing personal risk in order to deter making war-humanitarian intervention. Libya is the poster child for a new model of humanitarian intervention in which proxy ground forces combine with remotely-piloted air forces to drive the dictator from power. That is the only realistic circumstance in which avoidance of own-force casualties is a sufficiently large concern to be decisive in the use of force or not; everything else obeys a much more stringent test of national security interests.

Armed altruism, ironically, is the one area in which the use of armed drones, because they avoid risk to personnel and so lower the disincentive to resort to force, is likely to be a decisive argument. Even that, to judge by Libya, is a hard sell, because war has many other disincentives besides personal risk, including the billions of dollars spent on the Libya campaign, the depletion of weapons stores, uncertainties of result, and the "you broke it, you bought it" problem after the immediate fighting ends. If drones were pioneered in the follow-on engagement to Charlie Wilson's War, they become a decisive weapon for risk-averse NATO powers in Samantha Power's War.

It is, however, quite likely that the development of technologies that allow for more discrete and targeted uses of force will incentivize more of them. One might call it "intelligence-driven uses of force" — a less felicitous, but perhaps more accurate, alternative phrase to "covert action." Drones are likely to increase those uses of force-not so much on account of lessened personal risk to forces, as on account of the precision in the weapon and the ability to engage in long-run intelligence gathering so to strike the target precisely as one wishes, and when. The trade-off will be between human special ops strike teams that can gather laptops, paper, other intelligence materials - and conceivably, should the United States ever return to the practice, capture and interrogate people — and drones that, unlike most human teams, wait for exactly the opportune moment to strike, but which cannot collect the left-overs.

One can say, certainly, that this increases the propensity to resort to force-and in practical terms, looking not just to the United States but also to other countries, as these technologies inevitably cheapen and become widely available, they will allow more instances of the use of force on the cheap and often with at least some deniability. There will be more assassinations and more assassination attempts, and much greater temptations to settle international affairs through apparently discrete, and occasionally even discreet, uses of force in this way. Again, however, we must be aware of the limits already discussed. Drones as a means of doing this are not some stealthy bird of prey, free-floating and alone; they require considerable infrastructure and, above all, on the ground intelligence. State actors who fear such interventions will quickly develop means of detection and counters, some kinetic and some not; the primary utility is likely to remain non-state actors of various kinds; Qaddafi's error, by this calculus, apart from not having a nuclear 


\section{Making the Use of Force Too Easy?}

deterrent, was to have invited attack too soon, before counter-drone technologies have become widely available to states.

I have argued elsewhere that the development of these capabilities calls for the development of new legal standards that are neither law enforcement rules nor conventional armed conflict rules to govern these "intelligence driven uses of force". ${ }^{12}$ But it would be an analytic mistake to assume that because there are more such interventions, that it's sufficient to say that they are too easy or too many. After all, uses of force need to be measured not just by their number, but also by their intensity. In any case, drones and targeted killing open a new chapter, but emphatically do not settle, the long standing debate over whether opportune covert action can head off greater trouble and conventional war ahead-or instead compound the unpleasantness and tend to lead to war that is wider, more intense, or undertaken more often down the road.

This leaves the argument, however, back where it began with the anger of professional military over the entirely removed, neutral, distanced, and abstract argument over whether drones remove too much personal risk from the forces under command. In part the anger is directed at the way in which its supposed objectivity allows American professors to remove themselves in their criticism from the community of people who are part of a side. The academic critics benefit from the protection of the community, but then stand arrogantly outside the terms on which it is protected and discount the sacrifices of those who provide that protection. I will return to this consideration of the moral role of "sides" in a conflict briefly in the conclusion.

But there is a narrower and more specific ground of anger and objection on the part of professional military and warfighters here. It lies from a profound sense that the lives of soldiers are being treated as mere means, to another end, by critics who have no moral warrant from the community to do so. This might initially seem odd, as we have been instructed by Walzer on the ways in which the "War Convention" is about the implicit social contract of war by which soldiers are treated as means, material in war. ${ }^{13}$ Nothing new about men as cannon fodder. But this misses the point of the anger. Soldiers accept that they are material of war, to be used as means and sacrificed on the altar of military necessity, and that sometimes the agreedupon rules of conduct that protect civilians will involve risks to them that might be avoided by acting however one liked. The "War Convention," as Walzer describes it, is a pact within jus in bello - a pact about the conduct of war, and the agreement that combatants are indeed mere means to the ends of military necessity.

12 Kenneth Anderson, "Law and Order: Targeted Killing is legitimate and defensible," The Weekly Standard, June 6, 2011 <http://www.weeklystandard.com/articles/law-and-order_571630. html> accessed November 3, 2011.

13 Michael Walzer, Just and Unjust Wars: A Moral Argument with Historical Illustrations (Basic Books Press, 1977). 


\section{Targeted Killings}

The critics' insistence on personal risks as against riskless drones, however, uses soldiers as means in quite a distinct sense. When it comes to the resort to force, whose decisions matter? The actors in that case are not the soldiers themselves, but instead the political leadership that makes the decisions of jus ad bellum, resort to force. The demand to put soldiers at risk is not actually to influence their behaviorbut instead the behavior of their political leadership. The force of the demand to expose personnel to personal risks rather than use drones is not intended to influence their behavior, but instead to use them as hostages against the decisions of their leadership. This is to use them as "mere" means in a moral sense-and one that is distinctly different, and not morally covered by, the way in which the War Convention allows soldiers to be treated as means and materiel of war.

\section{The general argument is coherent}

So perhaps the two jus in bello assumptions are plausible, and perhaps even more than plausible. In that case, what about protecting one's forces from personal risk through the use of drones? The alleged moral and non-moral imperative of putting one's forces at personal risk should not be seen as unexceptionable, admirable as a sentiment, or beyond criticism. That said, however, we must nonetheless acknowledge that the general argument, the overall argument, is coherent. This merits explicit acknowledgment, particularly given that I have sharply challenged some of the assumptions made in support of it..

It is possible-it cannot be ruled out a priori-that the resort to force might be "too easy." If a coherent basis could be offered for saying what the proper propensity of the resort to force should be, then we might be able to assess whether the effects of reducing the harms of how war is conducted have so great an effect in encouraging the resort to force that two things follow. One is that there is, on its own terms, "too much" resort to force; more than would be otherwise optimal in the absence of these altered incentives that, however ironically, result from reduced harms from war. The second is that there might be "too much" resort to force in another sense; not only relative to the "efficient" propensity to use force, but also relative to all the harms caused both by resort to force (the jus ad bellum consequences) and the harms caused to innocents in the conduct of war despite the more limited nature of harms from drones (the jus in bello consequences). These seem unlikely to me, but they cannot be ruled out a priori. The consequences from "too easy" resort to force might turn out to be far worse than the benefits conferred in a total-welfare sense, assuming of course that we could determine the "efficient" level of resort to force against which to assess any of this.

Framed as a general observation, although it is ironic that changes in war that make it less harmful to civilians and more protective of fighters might also have the 


\section{Making the Use of Force Too Easy?}

unintended consequence of making resort to force "too easy," it might nonetheless be so. It cannot be ruled out tout court. Indeed, it might qualify as "tragic" in Isaiah Berlin's criteria of tragedy arising from the inability to bring about a unity of the good: plural goods and values that cannot be reconciled, in this case perfect conduct in war but optimal resistance to engaging in it.

\section{VII. “Too easy”?}

We have accepted that setting out the sophisticated version of the general argument (the one that unpacks the notion of "too easy" into its surprisingly complicated parts) is important in order properly to evaluate it. We have also accepted that the general argument is logically coherent. The question, then, is whether we accept the coherence of the notion of "too easy" in the context of jus ad bellum. This is to say, yes, the development of new ways of fighting that bring about positive changes in matters of jus in bello can have the effect, at least in principle, of making the resort to force, jus ad bellum, easier. The question is whether it is coherent to go from "easier" to "too easy."

"Too easy" demands comparison to something, some standard of what resort to force should be. How would one know when one was resorting to force at the optimal point? What would that mean? Let us stipulate all such measurements are inherently imprecise and difficult to make. The problem is to determine whether there is, even in principle, an optimal social welfare-maximizing point for the resort to force. I do not believe there is, at least not in the neutral, mere cost-benefit analysis way in which this proposition of "efficiency" proposes to separate itself from purely moral criteria.

Efficiency proposes that we extract the net benefits over costs. ${ }^{14}$ As a proposition of social welfare in which there are multiple parties, the notion of welfare-maximizing efficiency starts from the idea that all costs and benefits are internalized in order to reach the point of net maximum social welfare for society as a whole. So-called Coase bargaining asks what happens when we have two (or more) parties with conflicting interests, conflicting costs and benefits; the classic example is "farmers" and "ranchers." The parties bargain to the efficient point, through payoffs between the parties. If the farmers and ranchers, with their conflicting requirements, were all part of the same enterprise, presumably the heads of that enterprise would make a rational choice that would internalize costs and benefits for the ranchers and the farmers taken together, and reach an efficient point of how much grain and how many cattle.

Where ranchers and farmers are not part of a common enterprise that will do this cost-benefit "netting" internally, Coase substitutes the market, with money

14 This discussion leaves aside a more technical (though quite interesting) framing by reference to Pareto efficiency and Kaldor-Hicks efficiency concepts. 


\section{Targeted Killings}

payoffs, to do the same thing. The market in this acts as a social mechanism that, even without making everyone part of the same enterprise, allows costs and benefits to be set against each other. But there must still be a mechanism of commonality, and for the farmers and ranchers, it is money. In order to bring about the net social welfare position, there has to be a common currency, by which payoffs can be made to bring the conflicting parties to the efficient point. Ranchers and farmers can pay each other. But what about war?

There are some wars for which that is true. It is particularly true of those that are mostly about extended banditry, war-lordism, control of diamond mines, and so on (leaving aside the many problems of parties keeping promises, defecting from bargains, etc.). In some of those cases one might in effect bribe parties away from resort to war. The losers in one sense might still count themselves the winners in another: equilibrium at last.

But many conflicts are not that way, and certainly not the historically most important. War in our historical world is not merely organized theft. The conflicts in which the United States engages are not that way; whatever its national security interests, if it has reached the point of war, it cannot be bought off by money or any other market "commonality" substitutes between the parties, and most of the time the party on the other side cannot be, either. The conflicts that matter to the United States involve sides that have interests, desires, ideologies, fears, motives, and reasons for fighting that are not only opposed to the other side-they will be unreachable by bargaining because there is no common currency, expressing a common framework of costs and benefits, and a "net" social welfare function, between them. Sides matter. Because sides matter, there is no ability to avoid the normative moral problem by trying to convert it into a merely neutral, technocratic problem of winners and losers paying each other off to reach the point of net social welfare.

Why does not efficiency jus in bello face the same problem? Perhaps it does, if one goes beyond military necessity as merely means to prior ends and treats the problem as Walzer's "importance of winning." It might or might not be coherent to do as the law of war does and confine the argument over military necessity to something that is limited to the situation on the concrete battlefield, connected perhaps to an overall strategic military aim, but not the political grand strategy of "winning." It is easier to see ways to weigh up seeming incommensurables of civilian harm and military necessity when military necessity is limited and made at the most concrete level in which "means to ends" is more obvious. Why this should be so remains a difficult and unresolved question of proportionality in jus in bello.

The peculiarity here is in part that the prong of jus in bello proportionality one might initially think is most connected to justice is civilian harm, rather than military necessity. After all, necessity of military means to military ends might 


\section{Making the Use of Force Too Easy?}

seem like a merely technocratic, rational choice exercise-cost-benefit analysis par excellence. Whereas civilian harm seems like an "excused injustice" done in the course of militarily necessary operations - excused yet still fundamentally a question of justice. Yet civilian harm, understood in another sense, turns out to be the least difficult as a category and far more closely related to cost-benefit analysis and concepts of net social welfare. Why? Because it is not so much about "justice" as it is about what it says, "harm"-for which, all things being equal, less is better. Harm to civilians might be about justice simpliciter, but it might well equally be regarded as "superior non-moral consequences." They come to the same thing in this case. However, this cannot be said of winning or losing the war as such because, well, one side wins and the other side loses. That makes them different, and incomparable in the sense of what each side will recognize as acceptable.

Moreover (and this is a slightly different point), what they each win or lose is not actually the same kind of thing or value. Winning is a different quality, when it comes to war, than losing, in the special sense that they are not simply opposites. We are used to thinking of winning and losing as the opposite sides of a coin, or the up and down sides of a single quality, laid out on a graph. That is misleading. The experience of what a side in war gains by winning is a distinctly different kind of experience and quality from that of the side that loses. Think about societies in war, either state-to-state wars, or civil wars - the winning and the losing are largely about different kinds of things.

Thus the ability to compare or "buy off" in Coasean bargaining to reach the efficient point in resort to force is not really there. Determining the net social welfare for when to resort to force would require a set of common grounds between parties of conflict that does not exist unless, perhaps, in the mind of God.

\section{Conclusion: social welfare that turns out to be justice}

The notion of efficiency in the resort to force thus turns out to be incoherent because there is no common ground of social welfare between the sides that would allow them to agree upon the efficient point, or a common currency that would allow them to bargain their way to it and pay each other off. They fight instead.

Not having available a common social criterion by which to define the efficient point of resort to force has the perhaps peculiar, perhaps unsurprising consequence of forcing the debate back to moral questions - the oldest question of jus ad bellum of all, which side is right? Which side has just cause? The interesting and important questions of "efficient" resort to force turn out to be the moral questions, the questions of the justice of the sides, and the notion of an efficient resort to force simply says, the resort to force is efficient when force is resorted to justly. It is a disguised way, under concealing if comforting rubrics of maximizing social welfare, 


\section{Targeted Killings}

of asking exactly the same moral questions about just cause in war. The two sides do not agree on the answers, but there is no neutral way of answering the question of whether one side or the other has resorted to force "too easily" without answering the question of the justness of the cause.

Note that this is not simply an invocation of some form of moral relativism-the two sides cannot agree, because there is no objective moral answer as to the just or unjust side-and therefore there is no basis for determining common social welfare, either. After all, the fact of moral disagreement is typically used as an argument in favor of appealing to neutral non-moral facts about benefit and harm to settle the question. In the case of sides in war, however, that form of argument is incoherent. But it is not because there cannot be, in principle, a moral answer; there might well be. The moral answer might be contested by the two sides; the problem for the efficiency argument, by contrast, is that it is genuinely incoherent, and not merely contested. Of course the sides disagree, with the result that any neutral or common answer to the question is itself a moral position, a question of justice and just cause. The apparently neutral, non-moral welfare criterion turns out to be an irreducibly moral one. And even if the resulting moral claim is contested, and indeed unknowable, that is not a claim of moral relativism. ${ }^{15}$

The same applies for the idea of "too easy" resort to force over a series of uses of force. The proper answer for whether a party finds it "too easy" to use force is to ask about the justice-including the economy of means and methods to minimize harms - of each individual intervention in the series. If each is just (applying here the full criteria of just war for simplicity, including necessity), then the level of use of force is correct; if some or all is unjust, then it is incorrect. But because the sides have fundamentally incommensurable ideas of social welfare in winning and losing, they lack a common currency by which, even in principle, they could bargain by payoffs to some efficient common end. To say that they can, in principle, is simply to insist upon rather cryptic, in the circumstances, language of non-moral social welfare for what, in fact, depends essentially upon moral evaluations. Resort to force is "too easy" if it results in unjust interventions; otherwise not.

This is a roundabout way to what is finally an uncomplicated point. The discussion has walked through a perhaps unnecessarily overstated version of the "too easy" argument in order to get at the distinct notions of efficiency jus in bello and efficiency jus ad bellum, and to show that the latter, in particular, is incoherent unless it is understood to simply recapitulate and depend utterly upon evaluations

15 I believe that this is approximately the position that Lincoln takes in the final paragraph of the Second Inaugural Address, in which he attempts to thread the needle between a moral absolutism, on the one hand, and moral relativism, on the other. Hence his abjuration to "finish the work we are in," with firmness in the right- but as God gives us to see the right. It is a marvelously subtle phrasing, seeking to find a way through without collapsing into either position, whether philosophically successful or not. 
from morality and justice, not simply non-moral social welfare criteria with which, presumably, rational people could not disagree. Rational people do disagree, and those disagreements in war amount to sides. To the extent that one can talk about net welfare in arguments over resorting to force, they will be determined by the evaluation of the arguments made by the sides resorting to force, which is to say, an irreducible appeal to the justness of each side's cause.

This is not to deny that changes in the technology of war-drones and precision targeting - with which this discussion began do not have an effect upon the propensity to make war. As armed humanitarian intervention in Libya suggests, and is likely to be repeated, the decision to resort to war can be made "easier" by means of warfare that reduce civilian harm and spare one's own forces. If there is a social science prediction that emerges from this chapter, it is that if there are more humanitarian interventions by the advanced militaries (that is, the sole advanced military) of the West, drones are very likely to figure at the center of intervention strategy. A local partner fighting on the ground backed up by drones in the sky.

But the number of interventions must also be modified by intensity; it might turn out to be that the ability to engage in more covert actions, intelligence-driven uses of force, against non-state actors especially, means fewer, much less intense, and much shorter conventional wars waged to try and destroy non-state terrorist groups. The ability to reach non-state terrorists taking haven in a failed or hostile state without having to fight one's way to it on the ground, and to attack it with precision, is on balance a good thing-even from the standpoint of reducing the amount of conventional war fighting that might otherwise occur. In any case, the question of the resort to force does not start from a common social welfare framework, and so finally the questions of efficiency are simply re-enactments of assertions of justice made by sides to a conflict that have incommensurable positions on winning and losing.

Drones can make the decision to resort to force "easier;" that is not the same, however, as making it "too easy." 